\title{
The Mediating Role of Adaptive Cognitive Emotion Regulation in the Effect of Deliberate Rumination upon Posttraumatic Growth
}

\author{
Ahu Arıcioğlu ${ }^{1, *}$ \\ ${ }^{1}$ Department of Counseling and Guidance, Faculty of Education, Pamukkale University, Denizli, Turkey \\ *Correspondence: Department of Counseling and Guidance, Faculty of Education, Pamukkale University, Denizli, \\ Turkey. E-mail: aaricioglu@pau.edu.tr https://orcid.org/0000-0002-1068-1175
}

Received: October 17, 2020

Accepted: September 7, $2021 \quad$ Online Published: October 17, 2021

doi:10.5430/wje.v11n5p61

URL: https://doi.org/10.5430/wje.v11n5p61

\begin{abstract}
In this study, the mediator role of adaptive cognitive emotion regulation in the effect of deliberate rumination upon posttraumatic growth was aimed to be analyzed. A convenience sample of 272 university students including 175 $(64,3 \%)$ females and 97 (35,7\%) males was recruited from a university in Denizli, Turkey. Ages of the participants ranged between 20 and 37 with an average age of 21.94 years $(\mathrm{SD}=1.69)$. The Posttraumatic Growth Inventory, Event Related Rumination Inventory and Cognitive Emotion Regulation Questionnaire were used for collecting the data. The data were analyzed using SPSS 23 and Amos 22 software packages. Deliberate rumination was determined to be significantly and positively correlated with posttraumatic growth $(\mathrm{r}=, 28, \mathrm{p}<, 01)$ and positive cognitive emotion regulation $(\mathrm{r}=, 25, \mathrm{p}<, 01)$. Moreover, positive cognitive emotion regulation was significantly and positively correlated with posttraumatic growth $(\mathrm{r}=, 27, \mathrm{p}<, 01)$. The results indicated that adaptive cognitive emotion regulation mediated the effect of deliberate rumination on posttraumatic growth. The results, limitations, and implications of the study were discussed.
\end{abstract}

Keywords: posttraumatic growth, deliberate rumination and adaptive cognitive emotion regulation, university students

\section{Introduction}

As a concept that has been emphasized in trauma studies in recent years, posttraumatic growth is possible to be considered as individuals' achieving better functionality in their life. According to Park (1998), having a traumatic experience is not enough for posttraumatic growth. The permanent effects of trauma depend on individuals' ontogenetic characteristics as well as the responses of their social environment to trauma. When considered in terms of ecological theory framework, changes within the systems add dimensions to trauma. Therefore, the social and family environment individuals lives in is remarkable in terms of trauma because individuals do not respond similarly to trauma. Previous studies have suggested that poor self-perception and dysfunctional environmental conditions feed trauma. Individual characteristics (coping strategies, self-confidence), environmental sources (social support, financial sources), and variables related to the traumatic event affect the level of posttraumatic growth level (Linley and Joseph, 2005).

Posttraumatic growth emphasizes the development of individuals' awareness related to life and psychological functionality related to previous level of adaptation. In posttraumatic growth, not only individuals survive but also experience changes regarded as important and gone beyond the previous status quo. Posttraumatic growth is not only a return to the initial level, rather, it is a very profound developmental experience for some people (Tedeschi and Calhoun, 2004).

Posttraumatic growth is possible to be a structure that is more adjustable to adolescents or adults rather than young children because posttraumatic growth refers to a set of established schemes changing after trauma. Besides, young people are expected to report more growth rather than the older as young people can be more open to learning and changing of this process than the ones who have learned life lessons before (Powell, Rosner, Butollo, Tedeschi, and Calhoun, 2003). 
The studies carried out on posttraumatic growth in the literature were frequently related to individuals' experiencing life crisis such as diseases like cancer (Dong et al., 2017), grief (Krosch \& Finch, 2017), sexual assault (Frazier \& Berman, 2008) and war (Maguen et al., 2006; Powell et al., 2003). Posttraumatic growth is noticed to appear in various people facing a wide range of traumatic situations.

It has been assumed that individuals have a general sense of meaning and aim guiding their behaviors and helps them understand the reasons of their behaviors. This hypothetical world provides an overview individuals can act inside. However, major crises are possible to cause remarkable difficulties in understanding the world. Posttraumatic growth does not appear directly as result of trauma; what is important in how much of this growth appears is the struggle of individuals with new realities (Tedeschi \& Calhoun, 1995). In other words, after the trauma, individuals are more possible to turn their cognitive reconstruction into a more resistant scheme against traumas, possible future events and fragmentation along with the changes in their life. These are experienced as posttraumatic growth.

What makes crisis experience transformative is its having an emotional component, not the lessons learned and intellectual reflections. Due to this effect and restructuring of basic components in the hypothetical world, growth is observed to cause qualitative and quantitative differences in trauma victims. Previous studies have revealed that individuals undergoing severe trauma report a significantly higher level of positive personal change when compared to the ones who have not reported trauma (Tedeschi \& Calhoun, 1996). It is possible to mention that individuals who have experienced considerable difficulties in their lives have improved their ability of accepting paradoxes of life and dealing with basic questions more clearly and satisfactorily.

There are five domains of posttraumatic growth (Tedeschi \& Calhoun, 2004):

- More appreciation of life, and changing priorities,

- Friendlier and more intimate relationships with others,

- Higher sense of personal strength,

- Realizing new possibilities and ways for their own lives,

- Mental development.

Different theories explaining the posttraumatic growth have been noticed in the literature. For example, the conceptual model of life crises and growth developed by Schaefer and Moss (1998) suggests that responses to life crises with stress are shaped by factors that interact with each other. According to this, the factors called as environmental and personal affect the experience of crisis and its aftermath and suggest that the cognitive assessment and coping mechanisms related to the event are the determinants of the trauma process.

The organismic valuing theory developed by Joseph \& Linley (2005), on the other hand, is based on the idea that human beings are entities with a growth tendency and have intrinsic motivation in this respect. Human beings have the capacity of knowing what is important for them and what the best aspect of their life is. These characteristics guide them to the state of psychological well-being and an existence giving more satisfaction. According to this theory, growth appears in four stages: tendency towards accomplishment, internalization/adaptation, interpretation, and psychological well-being.

Descriptive functional model developed by Tedeschi \& Calhoun (2004) addresses that it is not the traumatic events themselves, but the subsequent process that matters in the emergence of growth. The importance of the effect created by the event that happened at the beginning of the posttraumatic growth process is also emphasized in the model.

According to Joseph, Murphy, and Regel (2012), the emotional-cognitive processing model is similar to other theories in terms of the role of posttraumatic stress on growth, knowledge of the event for growth, the existence of conflict between the previous assumptions, and the cognitive processes for eliminating this conflict. On the other hand, it has been reported that a certain effect emerges depending upon cognitive processing process, and coping mechanisms can be developed accordingly. Another point is the necessity of transition from intrusive thinking to reflective thinking. When individuals manage passing to reflective thinking, new meanings about the experience are possible to be created and the conflict is overcome making new story of life meaningful.

As could be seen, many theories attempt to explain posttraumatic growth. What these theories have in common is their emphasizing the potential for individuals to develop despite posttraumatic stress. Another variable that is considered to be related to posttraumatic growth and discussed in this study is rumination. Rumination is a passive and repetitive focus of the person on the negative mood, symptoms, or the causes and consequences of this situation rather than solving the problem and making an effort to change the symptoms that cause discomfort or distress (Nolen-Hoeksema, Wisco, and Lyubomirsky, 2008). According to the definition of Calhoun, Cann, Tedeschi, and McMillan (2000), 
rumination is 'a way of thinking that involves repetitive problem-solving, reminiscence, or expectation arising in relation to the event experienced.' From a wider perspective, rumination does not only occur in relation to past experiences. Ruminative thoughts can also arise due to individuals' themselves, others, past, present, future, completed, incomplete, or more different situations (Papageorgiou \& Wells, 2004). Rumination is an important concept that is frequently investigated in terms of shedding light on how negative emotions develop and keep existing persistently (Smith \& Alloy, 2009).

Rumination is a concept that has been studied extensively in recent years. Studies have been trying to explain it within the framework of various theories and models. In the Response Styles Theory, rumination emerges as a reaction to depressive mood, which is defined as making negative inferences after a stressful life event and often remembering these negative thoughts and cognitions (Nolen-Hoeksema, 1991). In stress reactive rumination model, on the other hand, rumination is argued to occur before the onset of depression (Alloy et al., 2000). Ruminative thinking that causes emotional distress such as helplessness, sadness, and fear occurring immediately after the incident is called 'intrusive rumination.' Deliberate rumination as another type of ruminative thinking leads individuals to a more positive understanding helping them to grasp the event and re-establish beliefs and make meaning out of the distress experienced (Calhoun et al., 2010). Involuntary rumination style has been found to be associated with depression, whereas deliberate rumination style is associated with posttraumatic development (Cann et al., 2011). It has been observed that rumination does not have a negative effect upon posttraumatic growth. Cognitive emotion regulation is thought to be important in trauma survivors due to the need of describing traumatic experiences for cognitive processing of emotional material.

Emotion regulation can be defined as all the processes that can change, direct, and control the usual flow of emotions (Gross and Thompson, 2007). In other words, emotion regulation is individuals' ability of evaluating, controlling, monitoring, and changing their emotional responses to reach a goal they have determined (Wenar and Kerig, 2000). Emotion regulation is an important process that allows people to move towards their daily lives without much practice or exercise on their emotions. The emotion regulation process can sometimes fail, but it can still be extremely useful when emotion regulation strategies are used appropriately and in the right context.

Cognitive emotion regulation focuses on cognitive dimensions of emotion regulation. Cognitive emotion regulation strategies are categorized under two groups as adaptive and non-adaptive coping strategies (Garnefski et al., 2001). Adaptive coping strategies include positive reappraisal, positive refocus, putting into perspective, refocus on planning, and acceptance, whereas non-adaptive coping strategies involve rumination, catastrophizing, self-blame, and blaming others (Garnefski and Kraaij, 2007). Acceptance means individuals' accepting the event they experience and its resulting emotions. Positive reappraisal means adding a positive meaning to the event. The individual's thinking about enjoyable and pleasant issues about themselves rather than thinking about the actual event is called positive refocus. Putting into perspective means referring to relevant thoughts for comparing the event with other events to reduce its impact or severity. Refocus on planning implies thinking about what steps to take and how to deal with adverse events. Planning is the cognitive part of action-oriented coping, and this does not mean actual behavior to be displayed. Self-blaming, which is one of the non-adaptive coping strategies, refers to individuals' thoughts of blaming themselves for the event experienced. Rumination, on the other hand, involves constantly thinking about feelings and thoughts about negative events. Catastrophizing occurs when the individual thinks that the event they have experienced will get worse constantly. Finally, blaming others means blaming others for a bad incident and putting the responsibility of the incident on others (Garnefski, Baan, and Kraaij, 2005).

\section{Method}

\subsection{Participants and Procedures}

The study group included 272 students studying at Pamukkale University. There were 175 female $(64,3 \%)$ and 97 male students $(35,7 \%)$ in the study group. Participants' ages ranged from 20 to $37(x=21,94, d f=1,69)$.

Correlational survey model was used in the study. Correlational survey models aim at determining the existence and/or degree of co-change between two or more variables (Karasar, 2016).

\subsection{Measures}

\subsubsection{The Personal Information Form}

This form was developed by the researcher to obtain information about the trauma/traumas experienced by the students in the study group. The form included statements indicating the type of trauma experienced. 


\subsubsection{The Posttraumatic Growth Inventory}

The posttraumatic growth inventory (PTGI) developed by Tedeschi and Calhoun (1996) is a Likert-type scale with 21 items scored between 0 and 5 . The score range of the inventory varies from 0 to 105 . High scores indicate that the person has experienced a high level of growth after the traumatic experience. The inventory has five sub-dimensions, namely, relating to others, personal strengths, appreciation of life, new possibilities, and spiritual change (Tedeschi and Calhoun, 1996).

The scale was first adapted to Turkish by Dürü (2006). The reliability of the posttraumatic growth inventory was analyzed with Cronbach's alpha method. The internal consistency coefficient was calculated to be $\alpha=, 93$, and explained $67,84 \%$ of the variance. The distribution of the items to the five-factor structure was as follows: relating to others (items 15, 14, 17, 16, 3 and 9), new possibilities (items 6, 8, 20, and 21), personal strengths (items 2, 1, 7, and 13), spiritual change (items 10, 4, 11, and 19), and appreciation of life (items 18, 5, and 12). Cronbach's alpha internal consistency coefficient of the scale was calculated to be 93 . The internal consistency coefficient of the posttraumatic growth inventory was found to be $\alpha=.93(\mathrm{~N}=349)$ (Dürü, 2006). In the present study, the form of the inventory that was adapted into Turkish by Kağan, Güleç, Boysan, and Çavuş (2012) was used. The three-factor structure and the distribution of the items were as follows: changes in self-perception $(5,10,11,12,13,15,16,17,18$, and 19), changes in philosophy of life $(1,2,3,4,7$, and 14), and changes in relationships $(6,8,9,20$, and 21). Internal consistency coefficients were $\alpha=0,88$ for changes in self-perception, $\alpha=0,78$ for changes in philosophy of life, $\alpha=0,77$ for changes in relationships, and $\alpha=0,92$ for the overall items. Also, the 15 -day-interval test-retest intra-correlation was 0,83 for overall scores, and it ranged between 0,70 and 0,85 for the subscales. In the current study, Cronbach's alpha coefficient for this scale was determined to be 0,90 .

\subsubsection{The Event Related Rumination Inventory}

The event related rumination inventory (ERRI) developed by Cann et al. (2011) included two subscales as 'intrusive rumination' (items 1, 2, 3, 4, 5, 6, 7, 8, 9 and 10) and 'deliberate rumination' (items 11, 12, 13, 14, 15, 16, 17, 18, 19 and 20). The Turkish adaptation study of the inventory was conducted by Haselden (2014). The results of the exploratory and confirmatory factor analyses carried out to evaluate the construct validity indicated that the inventory had two subscales as 'intrusive/involuntary rumination' (items 1, 2, 3, 4, 5, 6, 7, 8, 9 and 10) and 'deliberate rumination' (items $11,12,13,14,15,16,17,18,19$ and 20). According to the results of the reliability analysis, Cronbach's alpha internal consistency coefficient was found to be 0,94 for the intrusive rumination subscale, 0,88 for the deliberate rumination subscale, and 0,94 for the overall scale. Eventually, the ERRI was determined to be a valid and reliable measurement tool evaluating two different rumination types in Turkey samples. As result of the validity-reliability analysis, Cronbach's alpha internal consistency coefficient was found to be 0,94 for involuntary ruminations and 0,91 for voluntary ruminations. The inventory was found to be reliable to evaluate voluntary and involuntary rumination in the sample of the present study. The deliberate rumination subscale of the scale was employed in this study. Cronbach's alpha coefficient of the scale was found as 0,87 in the current study.

\subsubsection{The Cognitive Emotion Regulation Questionnaire}

The cognitive emotion regulation questionnaire (CERQ) developed by Garnefski, Kraaij, and Spinhoven (2001) is a five-point Likert-type measuring instrument including 36 items. Cronbach's alpha value of the subscales in the original form of the CERQ varies between 0,67 and 0,81 . The questionnaire has 9 subscales including self-blame $(1,10,19$, and 28 ), acceptance $(2,11,20$, and 29$)$, rumination $(3,12,21$, and 30$)$, positive refocusing $(4,13,22$, and 31$)$, refocus on planning $(5,14,23$, and 32), positive reappraisal $(6,15,24$, and 33), putting into perspective $(7,16$, 25, and 34), catastrophizing $(8,17,26$, and 35), and blaming others $(9,18,27$, and 36). Onat and Otrar (2010) adapted the CERQ to Turkish and determined Cronbach's alpha value as $\alpha=, 784$ and the test-retest reliability coefficient as $r=1,00$. The present study used the acceptance, positive refocusing, refocus on planning, positive reappraisal, and putting into perspective subscales which all included adaptive emotion regulation strategies. In the current study, Cronbach's alpha coefficient for this scale was determined to be 0,87 .

\subsection{Data Analysis}

The data was analyzed using SPSS 23 and Amos 22 software packages. The multivariate analysis of variance was conducted to evaluate whether the scores obtained from the variables in the study differed according tp gender and type of traumatic experience. The relationships between rumination and cognitive emotion regulation which were the variables of the study were tested with Pearson's product-moment correlation analysis. 


\section{Results}

\subsection{Results of the Descriptive Analysis for Traumatic Life Events}

The characteristics of the traumatic experiences that the participants stated were analyzed and presented in Table 1.

Table 1. Characteristics of the Traumatic Experiences Stated by Participants

\begin{tabular}{lll}
\hline Traumatic events experienced by the participants & $\mathbf{N}$ & $\mathbf{\%}$ \\
\hline 1. A close relative, friend, or someone important to me passed away. & 207 & 76 \\
2. A relationship that was important to me ended. & 148 & 54 \\
3. I had a very serious health problem. & 50 & 18 \\
4. A close relative, friend or beloved one had a really serious health problem. & 155 & 57 \\
5. I was seriously injured in an accident. & 32 & 12 \\
6. Someone who is very close to me and I love had an accident that resulted in a serious injury. & 72 & 26 \\
7. I caused an accident that caused someone to be seriously injured. & 10 & 4 \\
8. The place where I live was severely damaged by fire or other natural causes. & 17 & 6 \\
9. I witnessed a friend or family member subjected to violence. & 72 & 26 \\
10. I was the victim of serious physical violence. & 15 & 5 \\
11. I was subjected to sexual violence. & 22 & 8 \\
12. I was subjected to severe physical abuse by someone close to me. & 22 & 8 \\
13. I was robbed or exposed to pickpocketing. & 12 & 4 \\
14. I was chased. & 50 & 18 \\
15. I experienced a traumatic event other than these: Please explain shortly. & 1 & 0.4 \\
$\quad$ Natural-borne & 131 & 48 \\
\hline Human induced & 141 & 52 \\
\hline
\end{tabular}

As could be seen in the table, the most frequently reported trauma was 'a close relative, friend, or someone important to me passed away' with $76 \%(\mathrm{n}=207)$, and the least frequently reported one was 'I experienced a traumatic event other than these' (I was involved in a military clash, or I served on the battlefield) with $0.04 \%(n=1)$.

The participants who experienced more than one traumatic event were also asked to answer the scale items based on the event that affected them the most. The data related to these answers were analyzed, and they were classified as human-induced or natural-borne events. Accordingly, $48 \%(\mathrm{n}=131)$ of the events that most affected the participants were found to be nature-related, while $52 \%(n=141)$ were human-induced experiences.

\subsection{Descriptive Statistics and Correlations among the Study Variables}

The correlations between deliberate rumination, positive cognitive emotion regulation, and posttraumatic growth were presented in Table 2 . Deliberate rumination was significantly and positively correlated with posttraumatic growth $(\mathrm{r}=, 28, \mathrm{p}<, 01)$ and positive cognitive emotion regulation $(\mathrm{r}=, 25, \mathrm{p}<, 01)$. Also, positive cognitive emotion regulation was significantly and positively correlated with posttraumatic growth $(\mathrm{r}=, 27, \mathrm{p}<, 01)$. It could be noticed that all of the variables were normally distributed (skewness $=-, 48$ to,- 27 ; kurtosis $=-, 29$ to, 56 ).

Table 2. Correlations and Descriptive Statistics Related to the Variables of the Study

\begin{tabular}{llllllll}
\hline Variable & 1 & 2 & 3 & Mean & SD & Skewness & Kurtosis \\
\hline 1. Deliberate Rumination & - & & 18,92 & 6,56 &,- 48 &,- 29 \\
2. Adaptive Cognitive Emotion Regulation &, $25^{* *}$ & & 64,33 & 11,15 &,- 35 &, 56 \\
3. Posttraumatic Growth &, $28^{* *}$ &, $27 * *$ & 79,01 & 17,48 &,- 27 &,- 09 \\
$* * p<.01$ & & & & & & \\
\hline
\end{tabular}

\subsection{Measurement Models}

In order to test the construct validity of the scales used, a single factor confirmatory factor analysis for the Purposeful Rumination Scale and a second level confirmatory factor analysis for the adaptive Cognitive Emotion Regulation and 
Posttraumatic Growth Scales were performed with AMOS 22 program. The fit values produced by the measurement models created to test the validity of the scales were presented in Table 1.

Table 3. Measurement Models of Study Variables

\begin{tabular}{lllllll}
\hline Model & $\chi 2$ & df & $\chi 2 /$ df & GFI & CFI & RMSEA \\
\hline CFA of Deliberate Rumination & 71,525 & 31 & 2,307 &, 949 &, 957 &, 069 \\
CFA of Positive Cognitive Emotion Regulation & 384,393 & 165 & 2,330 &, 874 &, 910 &, 070 \\
CFA of Posttraumatic Growth & 273,573 & 148 & 1,848 &, 912 &, 950 &, 056 \\
Through a measurement model & 211,831 & 122 & 1,736 &, 921 &, 946 &, 052 \\
Goodness of fit values* & & & $\leq 3$ & $\geq 0,90$ & $\geq 0,97$ & $\leq 0,05$ \\
Acceptable goodness of fit values* & & & $\leq 4-5$ & $0,89-0,85$ & $\geq 95$ & $0,06-0,08$ \\
\hline
\end{tabular}

$\mathrm{p}>.05$, Chi Square; $\mathrm{df}=$ Degree of Freedom; GFI=Goodness of Fit Index; CFI=Comparative Fit Index; RMSEA=Root Mean Square Error of Approximation

*Cited by: Meydan and Şeşen, 2011:37

Since the values in Table 3 were within acceptable limits, the one-dimensional structure of the deliberate rumination scale, the five-dimensional structure of the adaptive cognitive emotion regulation scale and the three-dimensional structure of the posttraumatic growth scale were confirmed.

Table 4. Parameters and $95 \%$ CIs for the Paths of the Final Model

\begin{tabular}{|c|c|c|c|c|}
\hline & \multicolumn{4}{|c|}{ Result variable } \\
\hline & \multicolumn{2}{|c|}{ Adaptive Cognitive Emotion Regulation } & \multicolumn{2}{|c|}{ Posttraumatic Growth } \\
\hline & $\beta$ & SE & $\beta$ & SE \\
\hline Deliberate Rumination (path c ) & & & $6,089^{*}$ & 1,335 \\
\hline $\mathrm{R}^{2}$ & & & \multicolumn{2}{|c|}{0,112} \\
\hline Adaptive Cognitive Emotion Regulation (path a) & $0,435^{*}$ & 0,168 & & \\
\hline $\mathrm{R}^{2}$ & & 0,060 & & \\
\hline Deliberate Rumination (path c' ) & & & $4,515^{*}$ & 1,318 \\
\hline Posttraumatic Growth (path b) & & & $2,243^{*}$ & 0,888 \\
\hline $\mathrm{R}^{2}$ & & & \multicolumn{2}{|c|}{0,136} \\
\hline Indirect effect & & $0,975 *(0,090-2,164)$ & & \\
\hline
\end{tabular}

The overall effect of deliberate rumination on posttraumatic growth was found to be statistically significant $(\beta=6,089$; $\mathrm{p}<0,001)$. A positive path coefficient was obtained between deliberate rumination and adaptive cognitive emotion regulation $(\beta=0,435 ; p<0,001)$. The indirect effect between deliberate rumination and posttraumatic growth was 0,975 , and a $95 \%$ confidence interval of $0.090-2.164$ was obtained. Since this interval did not include the value of 0 , the indirect effect was found to be statistically significant.

\section{Discussion and Conclusion}

In the present study, the type of trauma experienced was analyzed to obtain data about the traumas experienced by the students in the study group. Although there was no definite data on the number of individuals exposed to psychological trauma in the literature, Lee and Young, (2001) reported that the rate of people experiencing psychological trauma varied between $17,7 \%$ and $92,2 \%$. Karaman and Tarım (2018) determined that the most frequent trauma type was witnessing to the death of someone and the loss of the most beloved/closest person. In the present study, the most common type of trauma was 'a close relative, friend, or someone important to me passed away' with $76 \%(\mathrm{n}=207)$. This finding of the study was similar to the finding of the previous studies. This finding could be the result of the loss of grandparents in the family as a feature of the developmental period of university students.

This research was carried out to analyze the mediating role of adaptive cognitive emotion regulation in the effect of deliberate rumination on posttraumatic growth. Deliberate rumination leads individuals who try to comprehend the 
event and re-establish beliefs to a more positive understanding in which they can make sense of the distress they have experienced (Calhoun et al., 2010). In this study, deliberate ruminative thinking described as positive and had the potential of guiding the individual's perspective positively was found to be correlated with posttraumatic growth. The findings in the literature related to the fact that deliberate ruminative thinking mediated posttraumatic growth in cancer patients (Chan et al., 2011; Ogińska-Bulik, 2017) supported the findings of this present study.

The literature on posttraumatic growth indicated that deliberate rumination style positively predicted posttraumatic growth (Tripplet, Tedeschie, Cann, Calhoun, and Reeve, 2012; Lindstrom, Cann et al., 2013). It was found that the findings of this study were parallel to the relevant literature in terms of pointing out the relationship between deliberate rumination and posttraumatic growth.

According to Hagan (2015), trauma experience had the potential of changing the efficient use of emotion regulation strategies. Similarly, according to Tedeschi and Calhoun (2004), learning difficult emotion management styles increased the possibility of experiencing posttraumatic growth and enabled individuals to develop a different perspective towards the life story in the face of new crises. One of the findings of this study was that adaptive cognitive emotion regulation was the mediator variable in posttraumatic growth, and this finding of the study was consistent with the literature. A study on emotion regulation, self-esteem, and happiness conducted with 262 university students revealed that there was a positive relationship between emotion regulation, self-esteem, and happiness; emotion regulation was found to largely explain self-esteem and happiness (Demirtaş, 2018). As could be seen, adaptive cognitive emotion regulation was associated with positive variables. In other words, less use of adaptive cognitive emotion regulation strategies could be considered as a risk factor. Indeed, Yöş (2018) who studied the relationship between cognitive emotion regulation strategies and depression and anxiety with 350 university students and graduates found that those with high depression and anxiety scores used adaptive cognitive emotion regulation strategies less.

Parent-child relationships are important in acquisition of adaptive cognitive emotion regulation strategies. The finding of a study conducted with 158 families has revealed that adaptive emotion regulation skills are learned primarily in the context of parent-child interaction (Bridgett et al., 2011). Children's emotion regulation develops with the positive responses of others important to the child such as parents, teachers and peers. (Ulutaş \& Ömeroğlu, 2012). Psychological counselors are possible to conduct consultation services for families on cognitive emotion regulation strategies. Also, the guidance services of schools can develop prevention and improvement programs on emotion regulation strategies. In other words, psychological counselors working in schools are an indispensable part of school environments as they provide student personality services. It is important that school psychological counselors provide preventive mental health services. School psychological counselor provides the first mental health service in experiences such as emotion regulation, trauma in schools.

Addressing the relationship between rumination and posttraumatic growth in different cultures is especially valuable in the context of culture-sensitive counseling. For this reason, handling this relationship in different study groups is important in terms of understanding the relationship between these concepts. As in every study, this study has some limitations, too. The generalizability of the results is limited due to the use of a cross-sectional data collection method and convenience sampling. To eliminate these limitations, we recommend carrying out further studies repeating the results of the study using random sampling and longitudinal data collection method.

\section{Acknowledgements}

No potential conflict of interest was reported by the author

\section{References}

Alloy, L. B., Abramson, L. Y., Hogan, M. E., Whitehouse, W. G., Rose, D. T., Robinson, M. S., Kim, R. S., \& Lapkin, J. B. (2000). The Temple-Wisconsin Cognitive Vulnerability to Depression Project: Lifetime history of Axis I psychopathology in individuals at high and low cognitive risk for depression. Journal of Abnormal Psychology, 109(3), 403-418. https://doi.org/10.1037/0021-843X.109.3.403

Bridgett, D. J., Gartstein, M. A., Putnam, S. P., Lance, K. O., Iddins, E., Waits, R., et al. (2011). Emerging effortful control in toddlerhood: The role of infant orienting/regulation, maternal effortful control, and maternal time spent in caregiving activities. Infant Behavior \& Development, 34, 189-199. https://doi.org/10.1016/j.infbeh.2010.12.008 
Calhoun, L. G., Cann, A., \& Tedeschi, R. G. (2010). The posttraumatic growth model: Sociocultural considerations. In T. Weiss \& R. Berger (Eds.), Posttraumatic growth and culturally competent practice: Lessons learned from around the globe (pp. 1-14). John Wiley \& Sons Inc.

Calhoun, L. G., Cann, A., Tedeschi, R. G., \& McMillan, J. (2000). A correlational test of the relationship between post-traumatic growth, religion, and cognitive processing. Journal of Traumatic Stress, 13, 521-527. https://doi.org/10.1023/A:1007745627077

Cann, A., Calhoun, L. G., Tedeschi, R. G., Triplett, K. N., Vishnevsky, T., \& Lindstrom, C. M. (2011). Assessing posttraumatic cognitive processes: The Event Related Rumination Inventory. Anxiety, Stress, and Coping, 24, 137-156. https://doi.org/10.1080/10615806.2010.529901

Chan M. W., Ho S. M., Tedeschi R. G., \& Leung C. W. (2011) The valence of attentional bias and cancer-related rumination in posttraumatic stress and posttraumatic growth among women with breast cancer. Psychooncology, 20, 544-552. https://doi.org/10.1002/pon.1761

Demirtaş, A. S. (2018). Duygu düzenleme stratejileri ve benlik saygısının mutluluğu yordayıcılığı [The Predictive Roles of Emotion Regulation Strategies and Self-Esteem on Happiness]. Turkish Studies Educational Sciences, 13(11), 487-503. https://doi.org/10.7827/TurkishStudies. 13465

Dong, X., Li, G., Liu, C., Kong, L., Fang, Y., Kang, X., \& Li, P. (2017). The mediating role of resilience in the relationship between social support and posttraumatic growth among colorectal cancer survivors with permanent intestinal ostomies: A structural equation model analysis. European Journal of Oncology Nursing, 29, 47-52. https://doi.org/10.1016/j.ejon.2017.04.007

Dürü, Ç. (2006). Travma Sonrası Stres Belirtileri ve Travma Sonrası Büyümenin Çeşitli Değişkenler Açısından Incelenmesi ve Bir Model Önerisi [Exploring posttraumatic stress sysmptoms and posttraumatic growth with respect to some variables and proposing a model] (Unpublished doctoral dissertation). Hacettepe Üniversitesi Sosyal Bilimler Enstitüsü, Ankara.

Frazier, P. A., \& Berman, M. I. (2008). Posttraumatic growth following sexual assault. In Stephen Joseph\& P. Alex Linley (Eds.), Trauma, recovery, and growth: Positive psychological perspectives on posttraumatic stress, 161-181. John Wiley \& Sons, Inc.

Garnefski, N., \& Kraaij, V. (2007). The cognitive emotion regulation questionnaire. European Journal of Psychological Assessment, 23(3), 141-149. https://doi.org/10.1027/1015-5759.23.3.141

Garnefski, N., Baan, N., \& Kraaij, V. (2005). Psychological distress and cognitive emotion regulation strategies among farmers who fell victim to the foot-and-mouth crisis. Personality and Individual Differences, 38, 1317-1327. https://doi.org/10.1016/j.paid.2004.08.014

Garnefski, N., Kraaij, V., \& Spinhoven, P. (2001). Negative life events. cognitive emotion regulation and emotional problems. Personality and Individual Differences, https://doi.org/10.1016/S0191-8869(00)00113-6

Gross, J. J., \& Thompson, R. A. (2007). Handbook of emotion regulation. New York: Guilford Press.

Hagan, C. (2015). Emotion regulation and adherence to display rules after experiencing childhood trauma (Master's thesis, Duquesne University). Retrieved from https://dsc.duq.edu/etd/612

Haselden, M. (2014). Üniversite öğrencilerinde travma sonrası büyümeyi yordayan çeşitli değişkenlerin Türk ve Amerikan kültürlerinde incelenmesi: Bir model önerisi [Exploring Various Variables As Predictors of Posttraumatic Growth on University Students in Turkish and American Cultures: A Model Proposal] (Unpublished doctoral dissertation). Hacettepe Üniversitesi Sosyal Bilimler Enstitüsü, Ankara.

Joseph, S. A., \& Linley, P. A. (2005). Religion, spirituality, and posttraumatic growth: A systematic review. Mental Health, Religion \& Culture, 8(1), 1-11. https://doi.org/10.1080/1367467032000157981

Joseph, S., Murphy, D., \& Regel, S. (2012). An affective-cognitive processing model of post-traumatic growth. Clinical psychology \& psychotherapy, 19(4), 316-325. https://doi.org/10.1002/cpp.1798

Kağan, M., Güleç, M., Boysan, M., \& Çavuş, H. (2012). Travma Sonrası Büyüme Envanteri'nin Türkçe Versiyonunun Normal Toplumda Hiyerarşik Faktör Yapısı[Hierarchical Factor Structure of the Turkish Version of the Posttraumatic Growth Inventory in a Normal Population]. TAF Preventive Medicine Bulletin, 11(5). https://doi.org/10.5455/pmb.1323620200 
Karaman, Ö., \& Tarım, B. (2018). Travma Sonrası Büyüme, Sosyal Problem Çözme Ve İyimserlik Arasındaki İlişkilerin İncelenmesi [Investigation of the relationship between post-traumatic growth, social problem solving and optimism] . Dicle Üniversitesi Sosyal Bilimler Enstitüsü Dergisi, 20, 190-198.

Karasar, N. (2016). Bilimsel araştırma yöntemi. Ankara: Nobel Yayıncılık.

Krosch, D. J., \& Shakespeare-Finch, J. (2017). Grief, traumatic stress, and posttraumatic growth in women who have experienced pregnancy loss. Psychological Trauma: Theory, Research, Practice, and Policy, 9(4), 425. https://doi.org/10.1037/tra0000183

Lee, D., \& Young, K. (2001). Post-traumatic stress disorder: Diagnostic issues and epidemiology in adult survivors of traumatic events. International Review of Psychiatry, 13(3), 150-158. https://doi.org/10.1080/09540260120074000

Lindstrom, C. M., Cann, A., Calhoun, L. G., \& Tedeschi, R. G. (2013). The relationship of core belief challenge, rumination, disclosure, and sociocultural elements to posttraumatic growth. Psychological Trauma: Theory, Research, Practice, and Policy, 5(1), 50. https://doi.org/10.1037/a0022030

Linley, P., \& Joseph, S. (2005). The human capacity for growth through adversity. American Psychologist, 60, $262-264$.

Maguen, S., Vogt, D. S., King, L. A., King, D. W., \& Litz, B. T. (2006). Posttraumatic growth among Gulf War I veterans: The predictive role of deployment-related experiences and background characteristics. Journal of Loss and Trauma, 11(5), 373-388. https://doi.org/10.1080/15325020600672004

Meydan, C. H., \& Şeşen, H. (2011). Yapısal eşitlik modellemesi AMOS uygulamaları. Detay Yayıncılık, Ankara.

Nolen-Hoeksema, S. (1991). Responses to depression and their effects on the duration of depressive episodes. Journal of Abnormal Psychology, 100, 569-582.

Nolen-Hoeksema, S., Wisco, B. E., \& Lyubomirsky, S. (2008). Rethinking rumination. Perspectives on Psychological Science, 3(5), 400-424.

Ogińska-Bulik N. (2017) The negative and positive effects of trauma resulting from cancer-the role of personality and rumination. Current Issues in Personality Psychology, 5, 232-243. https://doi.org/10.5114/cipp.2017.67016

Onat, O., \& Otrar, M. (2010). Bilişsel duygu düzenleme ölçeğinin Türkçeye uyarlanması: Geçerlik ve güvenirlik çalışmaları [Adaptation of cognitive emotion regulation questionnaire to Turkish: validity and reliability studies]. M. Ü. Atatürk Eğitim Fakültesi Eğitim Bilimleri Dergisi, 31, 123-143.

Papageorgiou, C., \& Wells, A. (2004). Depressive rumination: Nature, theory, treatment. Chichester: Wiley.

Park C. L. (1998). Stres-related growth and thriving through coping: the roles of personality and cognitive processes. Journal of Social Issues, 54, 267-77.

Powell, S., Rosner, R., Butollo, W., Tedeschi, R. G., \& Calhoun, L. G. (2003). Posttraumatic growth after war: A study with former refugees and displaced people in Sarajevo. Journal of Clinical Psychology, 59, 71-83. https://doi.org/10.1002/jclp.10117

Schaefer, J. A., \& Moos, R. H. (1998). The context for posttraumatic growth: Life crises, individual and social resources, and coping. Posttraumatic growth: Positive changes in the aftermath of crisis, 99, 126.

Smith, J. M., \& Alloy, L. B. (2009). A roadmap to rumination: A review of the definition, assessment, and conceptualization of this multifaceted construct. Clinical Psychology Review, 29(2), 116-128. https://doi.org/10.1016/j.cpr.2008.10.003

Tedeschi, R. G., \& Calhoun, L. G. (1996). The Posttraumatic Growth Inventory: Measuring the positive legacy of trauma. Journal of traumatic stress, 9(3), 455-471.

Tedeschi, R. G., \& Calhoun, L. G. (2004). Posttraumatic growth: Conceptual foundations and empirical evidence. Psychological inquiry, 15(1), 1-18. https://doi.org/10.1207/s15327965pli1501_01

Tedeschi, R. G., \& Calhoun, L. G. (1995). Trauma and transformation: Growing in the aftermath of suffering. Sage Publications.

Triplett, K. N., Tedeschi, R. G., Cann, A., Calhoun, L. G., \& Reeve, C. L. (2012). Posttraumatic growth, meaning in life, and life satisfaction in response to trauma. Psychological Trauma: Theory, Research, Practice, and Policy, 4(4), 400. https://doi.org/10.1037/a0024204 
Ulutas, I., \& Omeroglu, E. (2012). Maternal attitudes, emotional intelligence and home environment and their relations with emotional intelligence of sixth years old children. Emotional Intelligence-New Perspectives and Applications, 167-180.

Wenar, C., \& Kerig, P. (2000). Developmental psychopathology: From infancy through adolescence (5th ed.). McGraw Hill Higher Education.

Yöş, B. (2018). Üniversite öğrencilerinde bilişsel duygu düzenleme stratejileri ile depresyon ve kaygı arasındaki ilişkinin incelenmesi [The investigatıon of the relationship between cognitive emotion regulation strategies and depression and anxiety in unvversity students] (Unpublished Master Thesis). Işık Üniversitesi, Sosyal Bilimler Enstitüsü, İstanbul.

\section{Copyrights}

Copyright for this article is retained by the author(s), with first publication rights granted to the journal.

This is an open-access article distributed under the terms and conditions of the Creative Commons Attribution license (http://creativecommons.org/licenses/by/4.0/). 